Bruna Cristina Favoretto

\title{
Avaliação da participação dos receptores do tipo Toll e lectinas tipo C na supressão da resposta imune induzida por componentes de alta massa molecular do extrato de
}

\section{Ascaris suum}

Dissertação apresentada ao Programa de Pós-Graduação em Imunologia do Instituto de Ciências Biomédicas da Universidade de São Paulo, para obtenção do Título de Mestre em Ciências.

Área de concentração: Imunologia

Orientador: Dra. Eliana Faquim de Lima Mauro

SÃO PAULO 


\section{RESUMO}

FAVORETTO B. C. Avaliação da participação dos receptores do tipo Toll e lectinas tipo $\mathbf{C}$ na supressão da resposta imune induzida por componentes de alta massa molecular do extrato de Ascaris suum. 2010. 78 p. Dissertação (Mestrado em Imunologia) - Instituto de Ciências Biomédicas, Universidade de São Paulo, São Paulo, 2010.

Os helmintos, assim como seus antígenos são potentes imunomoduladores. Trabalhos realizados com extrato de Ascaris suum mostraram que os componentes de alta massa molecular (PI) contidos nele suprimem a resposta imune induzida por ovalbumina (OVA). PI inibe a expressão das moléculas MHC-II e coestimuladoras nas células dendríticas (DCs) e sua capacidade de induzir proliferação de linfócitos $T$ $\mathrm{CD}^{+}$, por mecanismo dependente de IL-10. As APCs, como as DCs, por meio de receptores expressos na membrana celular reconhecem os padrões moleculares presentes em patógenos e direcionam a resposta imune efetora. Neste trabalho avaliamos a participação dos receptores do tipo Toll 2 e 4 (TLRs) e de lectina tipo C (CLRs) expressos nas APCs na supressão induzida por PI. Observamos que a imunização dos camundongos com OVA/CFA promoveu aumento progressivo da expressão de TLR1, 2 e 4 nas células linfóides com pico entre $5^{\circ}-6^{\circ}$ dia pósimunização, exceto o TLR9 cuja expressão aumentou no $4^{\circ}$ dia e se manteve nos demais dias estudados. Entretanto, o PI foi capaz de inibir a expressão de TLR2 e 4

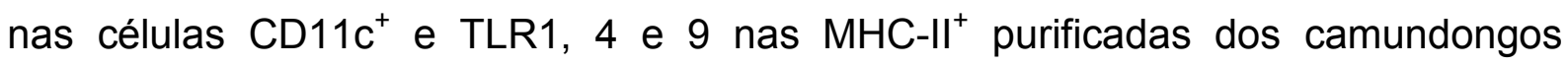
imunizados 5 dias antes com OVA+PI. Experimentos realizados em camundongos deficientes em TLR4 ou 2 mostraram que o PI suprimiu a resposta celular e humoral OVA-específica bem como a expressão das moléculas de MHC-II e coestimuladoras nas células destes animais imunizados com OVA+PI mostrando, portanto que PI exerce seu efeito modulador independente destes receptores. Em ensaios in vitro, o PI inibiu a maturação de DCs diferenciadas com GM-CSF/IL-4 e incubadas com agonistas de TLR 2, 3 ou 4. Além disso, em outros ensaios realizados in vitro com ligante de CLRs (manana) permitem sugerir que estes receptores participam do reconhecimento do $\mathrm{PI}$ e assim do seu efeito imunomodulador.

Palavras-chave: Imunossupressão. Células dendríticas. (PI). Extrato de Ascaris suum. Receptores de antígenos. Reconhecimento. 


\begin{abstract}
FAVORETTO B. C. Evaluation of the involvement of Toll like and C-type lectin receptors in the immunessuppression induced by high molecular weight components from Ascaris suum extract. 2010. 78 p. Master thesis (Immunology) Instituto de Ciências Biomédicas, Universidade de São Paulo, São Paulo, 2010.
\end{abstract}

Helminths, as antigens derived from them are potent immunomodulators. It has been shown that high molecular weight components (PI) from Ascaris suum extract exert a suppressive effect on immune response induced by ovalbumin (OVA). The PI components down-modulate the MHC class II and costimulatory molecules expression on dendritic cells (DCs) and the ability of these cells to induce TCD4 ${ }^{+}$ proliferation, via an IL-10-dependent mechanism. The antigen-presenting-cells (APCs), as DCs, via membrane receptors, recognize molecular patterns found in distinct pathogens and modulate the effector immune response. In this work, we analyzed the participation of the toll like 2 and 4 (TLRs) and the C-type lectin receptors (CLRs) expressed by APCs in the suppression induced by $\mathrm{PI}$. We observed that OVA/CFA immunization of mice promoted the progressive increase of TLR1, 2 e 4 expression on lymphoid cells with the peak between the $5^{-6} 6^{\text {th }}$ day after immunization, except for the TLR9 expression that increased on day $4^{\text {th }}$ and was maintained for all days studied. However, the PI was able to inhibit the TLR2 and 4 expression on purified CD11 $\mathrm{c}^{+}$cells and the TLR1, 4 and 9 on MHC class $\mathrm{II}^{+}$cells from mice immunized 5 days before with OVA plus PI. Experiments realized in TLR4 or 2 deficient mice showed that the PI suppressed the OVA-specific cellular and humoral responses as well as the MHC class II and costimulatory molecules expression on cells of these OVA plus PI immunized mice, showing that the PI components exert its modulator effect independent of these receptors. It was also observed that the $\mathrm{PI}$ inhibited the DCs maturation derived in vitro from bone marrow of BALB/C mice with GM-SCF/IL-4 and incubated with TLR2, 3 or 4 agonists. Moreover, other in vitro assays developed with CLRs ligand (mannan) suggest that these receptors participate in the $\mathrm{PI}$ recognition and thus its immunomodulator effect.

Key words: Immunessuppression. Dendritic cells. High molecular weight components (PI). Ascaris suum extract. Antigen receptor. Recognition. 


\section{INTRODUÇÃO}

Infecções por helmintos induzem em seu hospedeiro alta produção de anticorpos $\operatorname{lgE}$, eosinofilia e mastocitose, características de resposta tipo Th2 (ISHIZAKA; ISHIZAKA; TADA, 1969; JARRET e MILLER, 1982; SHER e COLLEY 1989; STREET et al., 1990). Em modelos de infecções com estes parasitas associadas a imunizações com antígenos não-relacionados demonstrou-se a capacidade destes patógenos de modular a resposta imune heteróloga (ORR e BLAIR, 1969; BARRIGA e INGALLS, 1984; JARRET e STEWART, 1972; KOJIMA e OVARY, 1975; HAIG; LIMA; MOTA, 1980).

Estudos evidenciaram a relação inversa entre infecções por helmintos e o desenvolvimento de doenças alérgicas e inflamatórias, possivelmente mediada por mecanismo dependente de células $T$ reguladoras geradas em resposta a estes parasitas (KHAN et al., 2002; ELLIOTT et al., 2003; ELLIOTT; SUMMERS; WEINSTOCK, 2005; MORREELS e PELCKMANS, 2005).

Assim como observado nas infecções helmínticas, extratos preparados a partir destes parasitas e seus antígenos solúveis são capazes de modular a resposta imune dirigida contra antígenos não relacionados (STROMBERG 1980; KOMATSU et al., 1979). Trabalhos realizados com o extrato de vermes adultos de Ascaris suum (Asc) demonstram sua capacidade de supressão da resposta imune humoral e celular induzida por ovalbumina (OVA) ou micobactéria (SOARES; MACEDO; MOTA, 1987; MACEDO e BARBUTO, 1988; FERREIRA et al., 1995). Componentes de alta massa molecular desse extrato de Asc (PI) são os responsáveis pelo efeito imunomodulador, enquanto que os de baixa massa molecular (PIII), obtidos por gel filtração, promovem altos títulos de anticorpos IgE Asc-específicos (SOARES; MOTA; MACEDO, 1992).

Duas proteínas do extrato de Asc, denominadas PAS-1 e APAS-3, foram isoladas por cromatografia de afinidade em resina acoplada à anticorpos monoclonais anti-PI ou anti-PIII. Em modelo murino de asma experimental, foi observado que PAS-1 apresenta atividade imunossupressora, enquanto que o APAS-3 induz a produção 
de $\lg E$, intensa inflamação eosinofílica e hiperreatividade das vias aéreas (ITAMI et al., 2003; OSHIRO; MACEDO; MACEDO-SOARES, 2005).

O estudo do efeito dos componentes isolados do Asc na resposta anti-OVA revelou que somente o $\mathrm{PI}$ é capaz de suprimir as reações de hipersensibilidade e a produção de anticorpos OVA-específicos em animais previamente imunizados com a OVA associada ao PI ou PIII. Observou-se ainda, inibição da resposta proliferativa e secreção de citocinas nas culturas de células dos animais imunizados com OVA e PI quando estimuladas in vitro com OVA ou concanavalina A (Con A) (FAQUIMMAURO e MACEDO, 1998).

Quando avaliada a resposta imune dirigida contra o PI ou PIII, foi constatada maior secreção de IL-4 e IL-10 e menor de IFN- $\gamma$ e IL-2 pelas células dos animais imunizados com $\mathrm{PI}$ ou $\mathrm{PIII}$ em resposta a estimulação in vitro com os próprios antígenos ou a Con A (FAQUIM-MAURO e MACEDO, 1998).

Durante o processo de indução da resposta imune adaptativa, as citocinas secretadas no microambiente de ativação das células $\mathrm{T}$ modulam e direcionam 0 perfil de células $\mathrm{T}$ efetoras e produção de anticorpos que serão geradas (GAJEWISKI e FITCH, 1988; FERNANDEZ-BOTRAN et al., 1988; FIORENTINO et al., 1991; DING et al., 1993; PEARLMAN et al., 1993).

Com relação ao efeito modulador do Asc na resposta imune anti-OVA, MACEDO et al. (1998) demonstraram que a IL-4 e IL-10 estão envolvidas neste processo, visto que o Asc foi incapaz de suprimir a resposta imune OVA-específica em animais inoculados com anticorpos anti-IL-4 e anti-IL10 in vivo antes da imunização com OVA e Asc. No entanto, a neutralização destas citocinas in vitro em culturas de células dos camundongos imunizados com OVA e Asc não foi capaz de restaurar a resposta proliferativa e secreção de citocinas anti-OVA à mesma magnitude observada nas células de camundongos imunizados somente com a OVA. Estes resultados sugerem, portanto que o efeito supressivo do Asc ocorre na fase de indução da resposta imune OVA-específica (MACEDO et al., 1998). Além dessas observações, experimentos realizados pelo nosso grupo mostraram diminuição na freqüência de células OVA-específicas na suspensão celular obtida de linfonodos de animais imunizados com OVA e Asc (dados não-publicados).

SOUZA; JACYSYN; MACEDO (2004) evidenciaram que a IL-4, induzida pelos componentes do $\mathrm{PI}$ (obtidos do Asc), é responsável pela inibição da síntese de 
IgG2a OVA-específica e a IL-10, por sua vez, exerce ação inibitória tanto na resposta Th1 como Th2 anti-OVA.

A ativação dos linfócitos $\mathrm{TCD}^{+}$é dependente da interação do seu complexo TCR/CD3 que conhece na membrana da célula apresentadora de antígeno (APCs) o peptídeo antigênico apresentado em molécula de classe II do complexo de histocompatibilidade principal (MHC). Além disso, é necessária a ligação entre as moléculas coestimuladoras (B7.1/B7.2 e CD40) expressas nas APCs com seus ligantes CD28 e CD40L na superfície dos linfócitos T (JUNE et al., 1994; PENG et al., 1996; KELSALL et al., 1996). Outra molécula que parece exercer papel relevante na coestimulação dos linfócitos T é a ICOS (inducible costimulator) que apresenta como ligante B7RP-1, ICOSL, GL50 ou LICOS, proteínas homólogas às B7 (BRODIE et al., 2000; LING et al., 2000; ARIMURA et al., 2002; WATANABE et al., 2005). Além do contanto celular, citocinas presentes nos tecidos linfóides são fundamentais para a geração da resposta efetora dos linfócitos T (JUNE et al., 1994; PENG et al., 1996; KELSALL et al., 1996; DIEHL et al., 2000; MACDONALD, 2002; STRAW, 2003; O`SULLIVAN et al., 2003).

As células dendríticas (DCs) exercem papel de destaque nesse processo, visto que são especializadas na captura e processamento do antígeno, migração para os órgãos linfóides e apresentação dos peptídeos antigênicos em moléculas de MHC e a expressão das moléculas coestimuladoras (SHORTMAN e LIU, 2002; CHAIN, 2003; BOONSTRA et al., 2003).

O reconhecimento dos diferentes microorganismos pelas APCs, como as DCs, é feito por receptores expressos em sua membrana celular, os quais se ligam a padrões moleculares presentes em patógenos, como lipopolissacarídeos (LPS), lipoproteínas, ácidos nucléicos e carboidratos (MOLL, 2003). Dentre estes receptores estão os do tipo Toll (Toll like receptor-TLR) e os da família de receptores de lectina tipo C (C-type lectin receptor-CLR) que, ligados seletivamente, geram sinais intracelulares de ativação e maturação celular, seguida de produção de mediadores solúveis, os quais podem determinar, durante a apresentação antigênica, a polarização dos linfócitos TCD4 ${ }^{+}$para Th1, Th2, Th17 ou Treguladores (MOSMANN e SAD, 1996, GAUSE et al., 1999; SCHNARE et al., 2001; TAKEDA; KAISHO; AKIRA, 2003; VAN KOOYK e GEIJTENBEEK, 2003).

D'OSTIANI et al. (2000) observaram que DCs incubadas com a forma de levedura de Candida albicans secretam IL-12 e assim, promovem a ativação e 
diferenciação dos linfócitos $T$ para Th1. Por outro lado, quando as DCs são incubadas com as hifas de Candida albicans induzem a geração de células Th2.

Em outro trabalho demonstrou-se que lipopolissacarídeos obtidos de duas bactérias distintas, Escherichia coli e Porphyromonas gingivalis, quando injetados com OVA ativam vias distintas de sinalização nas DCs, as quais culminam na geração de respostas polarizadas Th1 ou Th2 anti-OVA (PULENDRAM et al., 2001).

Os TLRs são diferenciados pelo tipo de antígeno que reconhecem, bem como pela sua localização e vias de sinalização intracelular. Na sua grande maioria, a ativação celular via TLR gera resposta inflamatória (AKIRA; YAMAMOTO; TAKEDA, 2003).

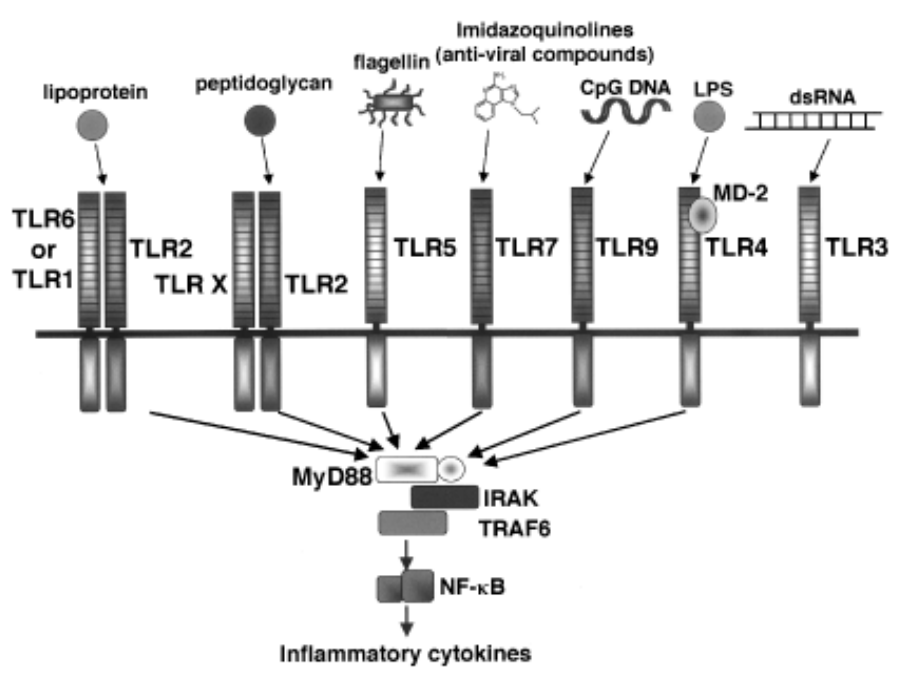

Figura 1- Sumário de ligantes reconhecidos pela família TLR. A resposta de todos os ligantes, exceto dsRNA, são dependentes da molécula adaptadora MyD88 responsável por ativar a cascata de proteínas intracelulares, culminando no fator de transcrição NFkB.

Fonte: AKIRA; YAMAMOTO; TAKEDA, 2003.

Com relação aos CLRs, estes reconhecem carboidratos associados às moléculas de maneira $\mathrm{Ca}^{+}$-dependente e também participam do processo de reconhecimento de antígenos, maturação das APCs e geração da resposta imune específica. Os receptores DC-SIGN e MGL são exemplos de CLRs que estão envolvidos no reconhecimento de glicanos presentes em patógenos/antígenos pelas DCs (MCGREAL, MILLER e GORDON, 2005; ZHOU et al., 2006).

Nas infecções por Wolbachia e Schistosoma mansoni foi mostrado que parte da inibição da resposta imune adaptativa é mediada pelo reconhecimento de antígenos destes parasitas via TLRs ou CLRs nas APCs e DCs que, por sua vez, promovem a indução de células T reguladoras e/ou secreção de citocinas inibitórias, como a IL-10 
(BRATTING et al., 2004; VAN DER KLEIJ et al., 2002).

BABU et al. (2005) observaram inibição da expressão de TLR1, 2, 4 e 9 em linfócitos $\mathrm{B}$ e monócitos obtidos de pacientes acometidos de filariose linfática. Posteriormente, estes autores (2006) mostraram menor expressão destes mesmos receptores nos linfócitos $\mathrm{T}$ de pacientes infectados por Brugia malay. Em conjunto, estes resultados sugerem que a imunossupressão observada em pacientes infectados por estes parasitas seja, portanto resultante da deficiência no reconhecimento dos antígenos via esses receptores.

Vários trabalhos têm descrito que o reconhecimento de patógenos distintos por CLRs podem desencadear sinais inibitórios ou estimulatórios nas DCs, o que resulta na modulação da atividade funcional destas células (ENGERING et al., 2002; GEIJTENBEEK et al., 2004).

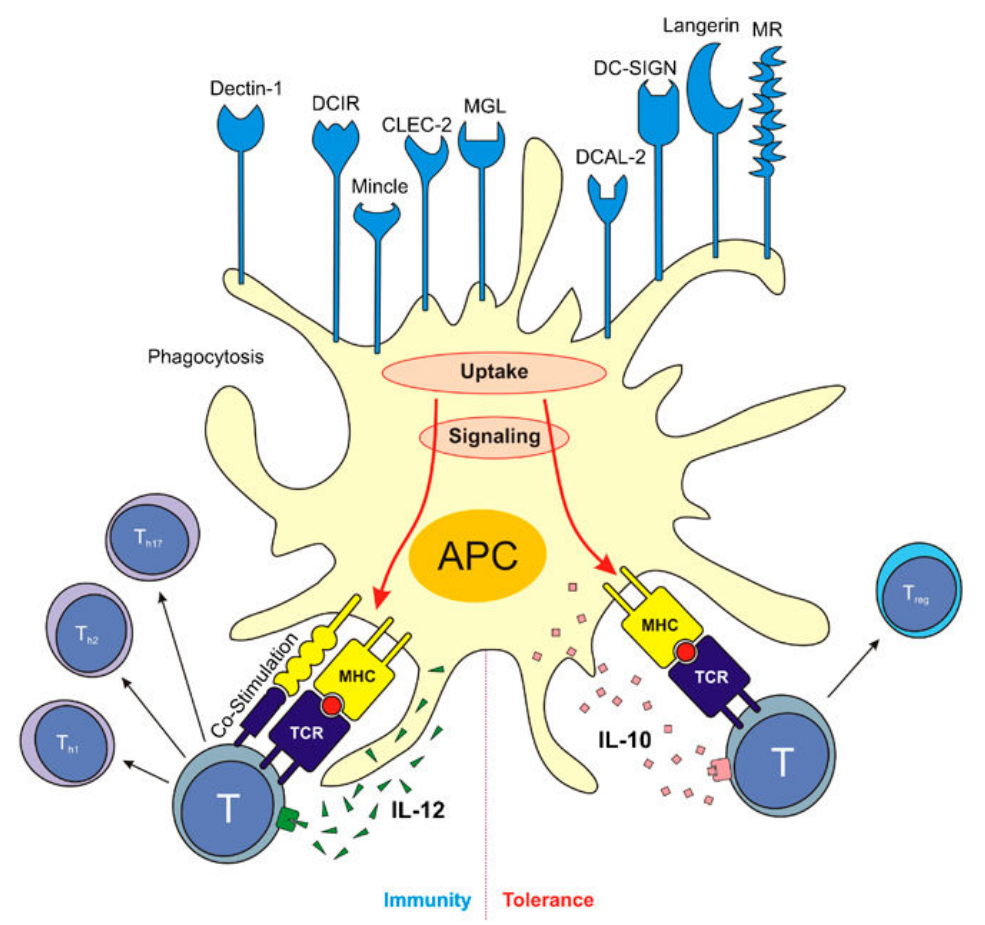

Figura 2- Função inata dos receptores de lectina tipo-C nos processos de captura de antígenos e sinalização intracelular em APCs. As APCs podem expressar vários CLRs que reconhecem estruturas específicas de carboidratos. Após a ligação os CLRs internalizam o antígeno para expressar em moléculas de MHC de classe I ou II para os linfócitos T. CLRs podem também ter função de molécula sinalizadora para a produção de citocinas. Na presença de sinalização via TLRs, moléculas coestimuladoras são positivamente reguladas e a captura por CLRs de antígeno e apresentação pode iniciar a estimulação de células T (Th1, Th2 e Th17). Na ausência de estímulos "de perigo" e coestimulação, a captura de antígeno pelos CLRs leva à apresentação para as células T e o desenvolvimento de tolerância através células $T$ reguladoras.

Fonte: VAN VLIET; GARCIA-VALLEJO; VAN KOOYK, 2008. 
VAN DIE et al. (2003) e VAN DIE e CUMMINGS (2006) mostraram que carboidratos presentes nos antígenos liberados pelos ovos do Schistosoma mansoni (SEA) são reconhecidos por receptores de lectina tipo C (DC-SIGN), receptores de manose e galactose expressos nas DCs e assim, inibem a ativação e maturação destas células induzida por ligantes de TLRs.

Com relação à modulação negativa da resposta imune por citocinas, nos últimos anos, a produção de IL-10 juntamente com a de TGF- $\beta$ (Transforming Growth Factor- $\beta$ ) tem sido diretamente associada à indução de células $T$ com atividade reguladora e inibição da atividade funcional das DCs (DOETZE et al., 2000; GRÜTZ, 2005).

Retomando a imunossupressão induzida pelos componentes de alta massa molecular do extrato de Asc (PI), SILVA et al. (2006) mostraram que esses antígenos inibem a expressão de moléculas de classe II do MHC e coestimuladoras tanto nas APCs (células MHC classe $\mathrm{II}^{+}$) como em DCs purificadas de camundongos imunizados com OVA e PI. Em ensaios in vitro, essas DCs foram incapazes de induzir a proliferação de linfócitos T OVA-específicos.

Experimentos realizados em camundongos geneticamente deficientes em IL-10 permitiram evidenciar que o PI foi incapaz de inibir a expressão das moléculas de classe II e coestimuladoras nas células destes animais imunizados com a OVA e PI. Ensaios in vitro também mostraram que $\mathrm{CD}_{11 \mathrm{C}^{+}}$purificadas de animais $\mathrm{IL}-10^{-/-}$ imunizados com OVA e estimuladas com OVA e PI foram eficientes em ativar linfócitos T OVA-específicos. Portanto, os resultados demonstram que a IL-10 é fundamental para que o PI exerça seu efeito nas células apresentadoras de antígeno e ainda, que a supressão da resposta anti-OVA induzida por PI é resultante da capacidade deste antígeno de modular a fase de indução da resposta imune específica. Considerando o papel central das APCs na geração da resposta adaptativa e ainda, que o reconhecimento dos patógenos/antígenos por estas células é um fator crucial na determinação do tipo de resposta imune que será gerada, fica evidente a importância em se estudar a participação destes receptores de membrana das APCs no processo de supressão da resposta imune induzida pelos componentes do $\mathrm{PI}$. 


\section{CONCLUSÕES}

$\checkmark$ PI é capaz de modular a expressão de receptores envolvidos com o reconhecimento de patógenos e antígenos microbianos (TLRs).

$\checkmark \mathrm{PI}$ exerce efeito inibitório na expressão das moléculas MHC de classe II e coestimuladoras em resposta a imunização com OVA em CFA ou IFA.

$\checkmark$ TLR 2 e TLR4 não estão envolvidos no efeito modulador do PI sobre as células apresentadoras de antígeno.

$\checkmark$ PI inibe a maturação de células dendríticas diferenciadas in vitro e estimuladas com agonistas de TLR2, 3 e 4.

$\checkmark$ Receptores de lectina tipo C parecem desempenhar papel relevante na modulação da atividade das DCs induzida por PI. 


\section{REFERÊNCIAS *}

AKIRA, S.; YAMAMOTO, M.; TAKEDA, K. Role of adapters in toll-like receptor signalling. Bioch. Soc., v. 31, p. 637-642, 2003.

ARIMURA, Y. et al. A co-stimulatory molecule on activated T cells, H4/ICOS, delivers specific signals in $\mathrm{T}(\mathrm{h})$ cells and regulates their responses. Int. Immunol., v. 14, p. 555-566, 2002.

$B A B U, S$. et al. Cutting edge: Diminished T cell TLR expression and function modulates the immune response in human filarial infection. J. Immunol., v. 176, p. 3885-3889, 2006.

BABU, S. et al. Diminished expression and function of TLR in lymphatic filariasis: a novel mechanism of immune dysregulation. J. Immunol., v. 175, p. 1170-1176, 2005.

BARRIGA, O. O; INGALLS, W. L. Potentiation of an IgE-like response to Bordetella bronchiseptica in pigs following Ascaris suum infection. Vet. Parasitol., v. 16, p. 343$5,1984$.

BOONSTRA, A. et al. Flexibility of mouse classical and plasmacytoid-derived dendritic cells in directing $T$ helper type 1 and 2 cell development: dependency on antigen dose and differential Tool-like receptor ligation. J. Exp. Med., v. 197, p. 101109, 2003.

BRATTIG, N. W. et al. The major surface protein of Wolbachia endosymbionts in filarial nematodes elicits immune responses through TLR2 and TLR4. Immunology, v. 173, p. $437-45,2004$.

BRODIE, D. et al. LICOS, a primordial costimulatory ligand? Curr. Biol., v. 10, p. 333-336, 2000.

CHAIN, B. M. Current issues in antigen presentation-focus on the dendritic cell. Immunol. Lett., v. 89, p. 237-241, 2003.

DEBRAY, H.; MONTREUIL, J.; FRANZ, H. Fine sugar specificity of the mistletoe (Viscum album) lectin I. Glycoconj J., v. 11, p. 550-7, 1994.

*De acordo com: ASSOCIAÇÃO BRASILEIRA DE NORMAS TÉCNICAS. NBR 6023: Informação e documentação: referências: elaboração. Rio de Janeiro, 2002. 
DIEHL, L. et al. The role of CD40 in peripheral T cell tolerance and immunity. J. Mol. Med., v. 78, p. 363-371, 2000.

DING, L. et al. IL-10 inhibits macrophage costimulatory activity by selectively inhibiting the up-regulation of B7 expression. J. Immunol., v. 151, p. 265-75, 1993.

DOETZE, A. et al. Antigen-specific cellular hyporesponsiveness in a chronic human helminth infections is mediated by $T$ (h)3/T (r) 1-type cytokines IL-10 and transforming growth factor-beta but not by a $T(h)$ to $T(h) 2$ shift. Int. Immunol., v. 12, p. 623-630, 2000.

D'OSTIANI, C. F. et al. Dendritic cells discriminate between yeasts and hyphae of the fungus Candida albicans. Implications for initiation of $\mathrm{T}$ helper cell immunity in vitro and in vivo. J. Exp. Med., v. 191, p. 1661-74, 2000.

ELLIOTT, D. E. et al. Exposure to schistosome eggs protects mice from TNBSinduced colitis. Am. J. Physiol. Gastroint. Liv. Physiol., v. 3, p. 385-391, 2003.

ELLIOTT, D. E.; SUMMERS, R. W.; WEINSTOCK, J. V. Helminths and the modulation of mucosal inflammation. Curr. Opin. Gastroent., v. 21, p. 51-58, 2005.

ENGERING, A. et al. Subset of DC-SIGN(+) dendritic cells in human blood transmits HIV-1 to T lymphocytes. Blood, v. 100, p. 1780-6, 2002.

FAQUIM-MAURO, E. L.; MACEDO, M. S. The immunosuppressive activity of Ascaris suum is due to high molecular weight components. Clin. Exp. Immunol., v. 114, p. 245-51, 1998.

FERNANDEZ-BOTRAN, R. et al. Lymphokine-mediated regulation of the proliferative response of clones of T helper 1 and T helper 2 cells. J. Exp. Med., v. 168, p. 543$58,1988$.

FERREIRA, A. P. et al. Immunization with Ascaris suum extract impairs $\mathrm{T}$ cell functions in mice. Cell. Immunol., v. 162, p. 202-10, 1995.

FIORENTINO, D. F. et al. IL-10 acts on the antigen-presenting cell to inhibit cytokine production by Th1 clones. J. Immunol., v. 146, p. 3444-51, 1991. 
GAJEWSKI, T. F.; FITCH, F. W. Anti-proliferative effect of IFN-gamma in immune regulation. I. IFN-gamma inhibits the proliferation of Th2 but not Th1 murine helper T lymphocyte clones. J. Immunol., v. 140, p. 4245-52, 1988.

GAUSE, W. C. et al. The development of CD4+ T effector cells during the type 2 immune response. Immunol. Res., v. 20, p. 55-65, 1999.

GEIJTENBEEK, T.B. et al. DC-SIGN, a dendritic cell-specific HIV-1-binding protein that enhances trans-infection of T cells. Cell, v. 100, p. 587-597, 2000.

GEIJTENBEEK, T. B. H. et al. Mycobacteria target DC-SIGN to suppress dendritic cell function. J. Exp. Medicine, v. 197, p. 7-17, 2003.

GEIJTENBEEK, T. B. H. et al. Self- and nonself-recognition by C-type lectins on dendritic cells. Annu. Rev. Immunol., v. 22, p. 33-54, 2004.

GOODRIDGE, H. S. et al. Immunomodulation via novel use of TLR4 by the filarial nematode phosphorylcholine-containing secreted product, ES-62. J. Immunol., v. 174, p. 284-293, 2005.

GRÜTZ, G. New insights into the molecular mechanism of interleukin-10-mediated immunosuppression. J. Leukoc. Biol., v. 77, p. 3-15, 2005.

HAIG, D. M.; LIMA, G. C.; MOTA, I. Antibody suppression in mice infected with Nippostrongylus brasiliensis. Parasite Immunol., v. 2, p.175-87, 1980.

HALARY, F. et al. Human cytomegalovirus binding to DC-SIGN is required for dendritic cell infection and target cell trans-infection. Immunity., v. 17, p. 653-64, 2002.

ISHIZAKA, K; ISHIZAKA, T.; TADA, T. Immunoglobulin E in the monkey. J. Immunol., v. 103, p. 445-53, 1969.

ITAMI , D.M. et al. Immunoglobulin $E$ is not required for but enhances airway inflammation and hyperresponsiveness. Allergy, v. 58, p. 1117-24, 2003.

JARRET, E. E.; MILLER, H. R. P. Production and activities of lgE in helminth infections. Prog. Allergy, v. 31, p. 178-233, 1982. 
JARRET, E. E.; STEWART, D. Potentiation of the rat reaginic (IgE) antibody by helminth infection. Simultaneous potentiation of separate regains. Immunology, $v$. 23, p. 749-755, 1972.

JUNE, C. H. et al. The B7 and CD28 receptor families. Immunol. Today, v. 15, p. 321-331, 1994.

KABELITZ, D. Expression and function of Toll-like receptors in T lymphocytes. Curr. Opin. Immunol., v. 19, p. 39-45, 2007.

KELSALL, B.L. et al. Interleukin-12 production by dendritic cells. The role of CD40CD40L interactions in Th1 T-cell responses. Ann. N. Y. Acad. Sci., v. 795, p. 11626, 1996.

KHAN, W. I. et al. Intestinal nematode infection ameliorates experimental colitis in mice. Infect. Immun., v. 11, p. 5931-5937, 2002.

KOJIMA, S.; OVARY, Z. Effect of Nippostrongylus brasiliensis infection on antihapten IgE antibody response in the mouse. II. Mechanism of potentiation of the IgE antibody response to a heterologous hapten-carrier conjugate. Cell Immunol., v. 17, p. 383-91, 1975.

KOMATSU, T. et al. Ascaris suum: suppression of the reaginic and hemagglutinating antibody responses in the mouse by crude extract and maintenance fluid. Exp. Parasitol., v. 47, p. 158-68, 1979.

LECHMANN, M. et al. Role of CD83 in the immunomodulation of dendritic cells. Int Arch. Allerg. Immunol., v. 129, p.113-8, 2002.

LIEW, F. Y.; XU. D.; BRINT, E. K. O'NEILL, L. A. J. Negative regulation of toll-like receptor-mediated immune responses. Nature, v. 5, p. 446-458, 2005.

LIM, SK. Freund adjuvant induces TLR2 but not TLR4 expression in the liver of mice. Int. Immunopharmaccol, v. 3, p. 115-8, 2003.

LING, V. et al. Cutting edge: identification of GL50, a novel B7-like protein that functionally binds to ICOS receptor. J. Immunol., v. 164, p. 1653-1657, 2000. 
MACDONALD, A. S. et al. Cutting edge: Th2 response induction by dendritic cells: a role for CD40. J. Immunol., v. 172, p. 1833-1838, 2002.

MACEDO, M. S.; BARBUTO, J. A. M. Murine delayed hypersensitivity is suppressed by Ascaris suum extract. Brazilian J. Med. Biol. Res., v. 21, p. 523-25, 1988.

MACEDO, M. S. et al. Immunomodulation induced by Ascaris suum extract in mice: effect of anti-interleukin-4 and interleukin-10 antibodies. Scand. J. Immunol., v. 47, p. 10-18, 1998.

MACLEOD, H.; WETZLER, L. M. T cell activation by TLRs: a role for TLRs in the adaptive immune response. Sci. Sign. v. 402, p. 1-2, 2007

MCGREAL, E. P; MILLER, J. L.; GORDON, S. Ligand recognition by antigenpresenting cell C-type lectin receptors. Cur. Op. Immunol., v. 17, p. 18-24, 2005.

MOLL, H. Dendritic cells and host resistance to infection. Cell. Microbiol., v. 5, p. 493-500, 2003.

MOLLER, B.; VILLIGER, P. M. Inhibition of IL-1, IL-6, and TNF-alpha in immunemediated inflammatory diseases. Spring. Sem. Immunopathol., v. 27, p. 391-408, 2006.

MOREELS, T.G.; PELCKMANS, P.A. Gastrointestinal parasites: potential therapy for refractory inflammatory bowel diseases. Inflamm. Bowel Dis., v. 11, p. 178-84, 2005.

MOSMANN, T.R.; SAD, S. The expanding universe of T-cell subsets: Th1, Th2 and more. Immunol. Today, v. 17, p. 138-146, 1996.

ORR, T. S. C.; BLAIR, A. M. J. N. Potentiated reagin response to egg albumin and conalbumin in Nippostrongylus brasiliensis-infected rats. Life Sci., v. 8, p.1073-7, 1969.

O'SULLIVAN, B.; THOMAS, R. CD40 and dendritic cell function. Crit Rev Immunol., v. 23, p. 83-107, 2003. 
OSHIRO, T.M; MACEDO, M.S.; MACEDO-SOARES, M.F. Anti-inflammatory activity of PAS-1, a protein component of Ascaris suum. Inflamm Res., v. 54, p. 17-21, 2005.

PEARLMAN, E. et al. Modulation of murine cytokine responses to Mycobacterial antigens by helminth-induced $T$ helper 2 cell responses. J. Immunol., v. 151, p. 1857-64, 1993.

PENG, $X$. et al. Acessory sig naling by CD40 for T cell activation: induction of Th1 and Th2 cytokines and synergy with interleukin-12 for interferon-gamma production. Eur J Immunol., v. 26, p. 1621-1627, 1996.

PETROVSKY, N.; AGUILAR, J. C. Vaccine adjuvants: current state and future trends. Immunol Cell Biol., v. 82, p. 488-96, 2004.

PRABHA, C., RAJASHREE, P., SULOCHANA, D. D. TLR2 and TLR4 expression on the immune cells of tuberculous pleural fluid. Immunol. Lett. v. 117, p. 26-34, 2008.

PULENDRAN, B. et al. Lipopolysaccharides from distinct pathogens induce different classes of immune responses in vivo. J. Immunol. v. 167, p. 5067-76, 2001.

SCHNARE, $M$. et al. Toll-like receptors control activation of adaptive immune responses. Nat. Immunol., v. 2, p. 947-950, 2001.

SHER, A.; COLLEY, D. G. Immunoparasitology. Fundament. Immunol., v. 2, p. 957-983, 1989.

SHIBAKI, A.; KATZ, S. I. Induction of shewed Th1/Th2 T-cell differentiation via subcutaneous immunization with Freud's adjuvant. Experiment. Dermatol., v. 11, p. 126-134, 2002.

SHORTMAN, K.; LIU, Y.J. Mouse and human dendritic cell subtypes. Nat. Rey Immunol., v. 3, p. 151-61, 2002.

SILVA, S. R. et al. Immunosuppressive components of Ascaris suum down-regulate expression of costimulatory molecules and function of antigen-presenting cells via an IL-10-mediated mechanism. J. Immunol., v. 36, p. 3227-37, 2006. 
SOARES, M. F. M.; MACEDO, M. S.; MOTA, I. Suppressive effect of Ascaris suum extract on IgE and IgG antibody responses in mice. Brazilian J. Biol. Res., v. 20, p. 203-11, 1987.

SOARES, M. F. M.; MOTA, I.; MACEDO, M. S. Isolation of Ascaris suum components which suppress IgE antibody responses. Int. Archs. Allergy Immunol., v. 97, p. $37-43,1992$.

SOUZA, V.M.; JACYSYN, J.F.; MACEDO, M. S. IL-4 and IL-10 are essential for immunosuppression induced by high molecular weight proteins from Ascaris suum. Cytokine, v. 28, p. 92-100, 2004.

STRAW, A. D. et al. CD154 plays a central role in regulation dendritic cell activation during infections that induce Th1 or Th2 responses. J. Immunol., v. 170, p. 727-734, 2003.

STREET, N. E. et al. Heterogeneity of mouse helper T cells: evidence from bulk cultures and limiting dilution cloning for precursors oh Th1 and Th2 cells. J. Immunol., v. 144, p. 1629-1639, 1990.

STROMBERG, E. E. Potentiation of a reaginic ( $\lg E)$ antibody response to ovalbumin in the guinea pig with a soluble metabolic product from Ascaris suum. J. Immunol., v. 125, p. 833-36, 1980.

SUDOWE, S. et al. The role of interleukin-4 in the regulation of sequential isotype switch from immunoglobulin $\mathrm{G} 1$ to immunoglobulin $\mathrm{E}$ antibody production. Scand. J. Immunol., v. 51, p. 461-71, 2000.

TAKEDA, K.; KAISHO, T.; AKIRA, S. Toll-like receptors. Annu. Rev. Immunol., v. 21, p. 335-376, 2003.

TSUJI, S. et al. Maturation of human dendritic cells by cell wall skeleton of Mycobacterium bovis bacillus Calmette-Guérin: involvement of toll-like receptors. Infect Immunol., v. 68, p. 6883-90, 2000.

VAN LIEMPT, E. et al. Schistossoma mansoni soluble egg antigens are internalized by human dendritic cells through multiple C-type lectins and suppress TLR-induced dendritic cell activation. Mol. Immunol., v. 44, p. 2605-2615, 2007. 
VAN DER KLEIJ, D. et al. A novel host-parasite lipid cross-talk. Schistosomal lysophosphatidylserine activates toll-like receptor 2 and affects immune polarization. J. Bio. Chem., v. 277, p. 48122-48129, 2002.

VAN DIE, I. et al. The dendritic cell-specific C-type lectin DC-SIGN is a receptor for Schistosoma mansoni egg antigens and recognizes the glycan antigen Lewis $\mathrm{x}$. Glycobiology., v. 13, p. 471-478, 2003.

VAN DIE, I. e CUMMINGS, R. D. Glycans modulate immune responses in helminth infections and allergy. Chem. Immunol. Allergy., v. 90, p. 91-112, 2006.

VAN KOOYK, Y.; GEIJTENBEEK, T. B. DC-SIGN: escape mechanism for pathogens. Nat. Rev. Immunol., v. 3, p. 697-709, 2003.

VAN VLIET, S.J., GARCIA-VALLEJO, J.J., VAN KOOYK, Y. Dendritic cells and Ctype lectin receptors: coupling innate to adaptive immune responses. Immunol Cell Biol., v. 86, p. 580-587, 2008.

VENUGOPAL, P. G.; NUTMAN, T. B.; SEMNANI, R. T. Activation and regulation of toll-like receptors (TLRs) helminth parasites. Immunol. Res., v. 43, p. 252-263, 2009.

WATANABE, M. et al. A distinct role for ICOS-mediated co-stimulatory signaling in CD4+ and CD8+ T cell subsets. Int. Immunol., v. 17, p. 269-278, 2005.

XIA, C. et al. Dendritic cells post-maturation are reprogrammed with heightened IFNy and IL-10. Bioch. and Biophys. R.C., v. 352, p. 960-965, 2007.

YOUNG-IK, SON. et al. Anovel bulk-culture for generating mature dendritic cells from mouse bone marrow cells. J. Immunol. Methods, v. 262, p. 145-157, 2002.

ZAR, J. H. Biostatistical Analysis. New Jersey: Printitice-Hall, 1974.

ZHOU, T. et al DC-SIGN and Immunoregulation. Cel. Mol. Immunol., v. 3, p. 279283, 2006. 